\title{
Juventude, boemia e movimentos sociais: culturas e lutas estudantis na universidade de Coimbra
}

\author{
Elísio Estanque
}

\section{Resumo}

O presente texto recupera trabalhos recentes do autor sobre a juventude estudantil de Coimbra. Centrado no ambiente universitário coimbrão e na tradição de uma academia com mais de 700 anos de história, o seu principal objetivo é o de questionar as tendências da atual juventude universitária, buscando, através de um olhar atento de um docente desde há mais de 20 anos envolvido no ambiente estudantil e no cotidiano da cidade, identificar subjetividades, lógicas de participação e atitudes de indiferença/demarcação entre os diferentes segmentos da população estudantil. Mais do que um registro fenomenológico do cotidiano da academia, pretende-se capturar experiências do passado e o modo como elas poderão (ou não) ser apropriadas pela atual geração de estudantes. Por outro lado, as profundas alterações ocorridas nas últimas décadas, quer no país quer no sistema de ensino superior português, reorientaram os comportamentos, as expectativas e as formas de ação da atual população universitária, levando-a a um distanciamento face a esse passado e a um "esquecimento" do significado dos movimentos estudantis, que nos anos 60 chegaram a abalar a ditadura de Salazar e Caetano. A reflexão que aqui se propõe pretende dar conta deste fenômeno, sem deixar de, ao mesmo tempo, olhar este contexto particular como expressão de outros fenômenos mais gerais com que se debatem hoje Portugal e as democracias europeias no seu conjunto.

Palavras-chave: juventude, universidade, Coimbra, estudantes, movimento estudantil, movimentos sociais, tradição, boemia.

Professor na Faculdade de Economia da Universidade de Coimbra e pesquisador do CES - Centro de Estudos Sociais da Universidade de Coimbra (Portugal). Endereço eletrônico: elisio.estanque@gmail.com. 


\title{
Introdução
}

\begin{abstract}
A afirmação da "juventude" enquanto sujeito social só ocorreu na Europa como resultado da consolidação do Estado providência e da extraordinária expansão do sistema de ensino por ele assegurado. Para tanto foi fundamental o surgimento da chamada "generation gap” que se impôs ao longo da década de 60 do século 20. Porém, a herança histórica desse legado geracional - até por ter sido em boa medida veiculada por alguns dos seus antigos protagonistas - acabou por dar lugar a uma espécie de "congelamento" de uma unidade imaginária dessa geração em torno do chamado "espírito de 68”, com isso construindo uma identidade histórica fictícia e dotada de um peso desmesurado, que se tornou impossível de suportar pelas gerações posteriores (CARDOSO, 2005). ${ }^{1}$
\end{abstract}

Esse processo de reconstrução ficcionada do passado caminhou de par com as novas tendências de mudança sociopolítica no ocidente. Assistiu-se na fase final da "guerra fria", a processos de institucionalização, individualização, crise e fragmentação do Estado social e das economias nacionais, ao triunfo da globalização neoliberal, ao desmoronamento do modelo socialista e à implosão das utopias que nos anos 60 animaram os movimentos sociais e estudantis. Mas, apesar da nova realidade ter pulverizado muitos dos idealismos em torno de uma mítica "rebelião mundial" promovida pelo radicalismo da classe média estudantil dos sixties, a sua herança continuou a fazer história, fosse pelas sucessivas releituras que suscitou em torno de novos activismos e movimentos progressistas (feministas, pacifistas, ambientalistas etc.), fosse pelos novos rumos que o capitalismo tomou sobretudo após o colapso soviético. Tiveram uma influência marcante quer no plano cultural quer no plano político, contaminando os modos de vida de suces-

1 Os resultados empíricos recolhidos através de questionários inserem-se na pesquisa Culturas Juvenis e Participação Cívica: diferença, indiferença e novos desafios democráticos, projeto financiado pela FCT - Fundação para a Ciência e Tecnologia/ Ministério da Ciência e do Ensino Superior, no POCTI/SOC/45489/2002. Alguns dos aspectos aqui abordados correspondem a adaptações e atualizações de publicações anteriores, designadamente um livro e dois artigos em periódicos em que o autor participou. 
sivas gerações e as formas de ação colectiva de velhos e de novos movimentos, de abrindo espaço a novas concepções, linguagens e referências ideológicas no plano social e institucional (EAGLETON, 1991; COHEN \& ARATO, 1992; EYERMAN e JAMISON, 1991; MELUCCI, 1996; TOURAINE, 1985 e 2006).

Os movimentos de há quarenta anos introduziram rupturas que ainda hoje se repercutem em múltiplos domínios. Pode dizer-se que os padrões de gosto desencadeados a partir dos movimentos juvenis dos anos 60 no ocidente - no plano estético, no vestuário, na música, nos interesses literários e intelectuais, na expressão da sexualidade etc. - não só alteraram o cotidiano e os modos de vida das gerações seguintes como dotaram a esfera pública e política de novos contornos. A importância da chamada crítica artística (BOLTANSKI \& CHIAPELLO, 2001) inseriu-se no processo de desconstrução culturalista que esses movimentos imprimiram (EDER, 1993), alterando até certo ponto a própria natureza do capitalismo, apesar das respostas que se seguiram - ou por causa delas - sob a ação canibalizadora das instituições e do mercado, abrindo caminho a novos valores e novas modalidades de ação colectiva, não apenas no mundo desenvolvido mas na escala internacional (HOLZMANN \& PADRÓS, 2003; CARDOSO, 2005). Por outro lado, sobretudo após a queda do muro de Berlim e o consequente colapso do império soviético, esbateram-se largamente as ideologias que durante mais de um século inspiraram os principais movimentos sociais sob formas de ação coletiva inspiradas em modelos utópicos de cariz emancipatório. No quadro deste processo, as novas tendências do capitalismo global vêm colocando novos obstáculos e desafios à ação coletiva, em larga medida esgotando os "velhos" movimentos e ao mesmo tempo estimulando novas redes e formas mais fluidas de "alter-globalização" e de ativismo no "ciberespaço" onde importantes segmentos juvenis intervêm permanentemente (RIBEIRO, 2000; SANTOS, 2004, 2005 e 2006; ESTANQUE, 2006).

É meu propósito neste texto refletir sobre as tendências recentes no campo da juventude e dos movimentos estudantis, mas ao mesmo tempo dar conta do contexto de Coimbra, com referências à tradição, às Repúblicas e também à luta estudantil 
dos anos 60, quando esta universidade se impôs, através dos seus estudantes, como um bastião da resistência ao Estado Novo e pelo fim da guerra colonial em África.

\section{Juventude, movimentos, boemia e tradição}

Desde a Revolução Industrial e ao longo da primeira modernidade as sociedades ocidentais construíram o Estado-Nação e promoveram a organização dos mercados e economias nacionais na base da idéia de progresso e de planejamento, procurando responder à exigência de controle do futuro e de regulação das expectativas (BECK, 2000 e 2006). O crescimento econômico do pós-guerra permitiu sustentar um Estado social que favoreceu importantes transformações e conquistas sociais, mas ao mesmo tempo que procurava programar o futuro, contribuiu, paradoxalmente, para proporcionar uma viragem de paradigma que fez emergir diversas perversões e entropias no sistema, dando lugar a novos protagonistas e movimentos anti-sistêmicos que, embora clamando por um "futuro agora", acrescentavam novas incertezas que mais tarde culminaram na "crise do futuro" (POMIAN, 1981 apud LECCARDI, 2005).

Foi nesse quadro que "a juventude" impôs-se como categoria social, intimamente associada à expansão do sistema de ensino em todos os seus níveis, incluindo o universitário. Mas, se o acesso à educação e o progressivo aumento da escolaridade levou a um alargamento cada vez maior do período de formação e, portanto, da fase de transição para a vida adulta, tal não implicou uma absoluta homogeneidade entre os jovens. De resto, se o fenômeno juvenil mereceu inicialmente a atenção dos teóricos, assinalando os seus traços convergentes enquanto geração (MANHEIM, 1952), foi, por outro lado, também sublinhada desde cedo a sua heterogeneidade, rejeitando-se, assim, a existência de uma "juventude" enquanto entidade uniforme, tendo ficado célebre a expressão de Bourdieu "la jeunesse n' est q' un mot" (1984). Tanto em termos sociais mais gerais como no caso da juventude universitária, os pontos de aproximação ou de clivagem entre diferentes segmentos juvenis não devem, porém, ser considerados em absoluto. Dependendo do nível de análise 
adotado e do próprio objeto de estudo, será sempre possível observar tanto convergências como divergências no seio de uma dada população ou numa mesma camada geracional. A própria mudança social em curso nas últimas décadas tem obrigado a rejeitar não só o critério etário - que de resto a sociologia sempre recusou (PAIS, 1990) - mas até a idéia de "transição para a vida adulta", isto é, de um período instável associado a uma semi-dependência (ou semiautonomia) correspondente a uma fase da trajetória evolutiva entre a família de origem e a de chegada, tem sido objeto de discussão e é hoje questionada pela maioria dos sociólogos (POLLOCK, 2002; LECCARDI, 2005; PAIS et al., 2005).

É certo que, no caso particular da juventude universitária, a suposta homogeneidade pareceu facilmente sustentável, sobretudo enquanto o acesso a este nível de ensino foi exclusivo das elites. Todavia, também a análise deste segmento - especialmente com a chegada de novos contingentes de jovens das mais diversas proveniências sociais - requer novas reformulações conceptuais que permitam um melhor ajustamento ao caráter mais complexo e heterogêneo deste segmento, antes de mais por se ter tornado desadequada a ideia de que a frequência do ensino universitário prenunciaria o acesso, no passo seguinte, a uma situação profissional cujo status seria compatível com o título acadêmico "superior". Ao mesmo tempo, importa realçar que as vivências do percurso universitário são, como sempre foram, diferenciadas. Ainda que hoje se possa falar de uma universidade "massificada", continuam presentes segmentos particulares de estudantes cujas práticas, subjetividades e orientações se pautam por padrões de vida e valores alternativos, distintos da maioria (e internamente diversificados).

Para alguns setores estudantis não é tanto a aprendizagem adquirida nas bibliotecas e salas de aula, mas sim as experiências adquiridas fora da instituição e em torno dela, que mais claramente irrigaram as suas potencialidades formativas, criativas e - em muitos casos - politicamente subversivas.

É provável que as modalidades clássicas de "boemia" e "tertúlia" estejam em vias de extinção ou a sofrer profundas alterações. Mas, até pelo simbolismo que transportam, vale a pena tê-las em conta a este propósito. $\mathrm{O}$ estilo de vida boêmio 
que floresceu em redor dos principais centros urbanos a partir do século 19 (MURGER, 1888) ${ }^{2}$ com as suas conotações com a vagabundagem, a errância, o descomprometimento e a irreverência ou, por exemplo, a cultura do riso carnavalesco, a imagem subversiva do corpo grotesco, das celebrações populares da época renascentista, projetadas na apologia da algazarra, do consumo de álcool e da promiscuidade sexual (BAKHTIN, 1999) ${ }^{3}$ ilustram alguns contornos dos ambientes estudantis que ao longo da Idade Média germinaram nas antigas "Nações", nos pubs e taverns das cidades universitárias da Europa (MOULIN, 1994).

No caso de Coimbra, as Repúblicas estudantis, com as suas formas alternativas de organização, de convívio, festa e de encontro com o desconhecido deram igualmente expressão a esse modo de vida (CARREIRO, 2002). Por isso constituem uma dimensão importante na análise do universo estudantil, quer para captar formas

2 Henri Murger contribuiu para popularizar a noção de boemia no sentido moderno a partir da peça Bohèmes du Quartier Latin (1849), que mais tarde deu origem ao ensaio aqui citado (no original Scènes da la Vie de Bohème). Os primeiros "boêmios" remontarão à Grécia clássica e referem-se a figuras famintas e erráticas, também associadas a ladrões e vagabundos, que circulavam por regiões abastadas e hospitaleiras pedindo pão, cantando e tocando lira em dedicação a Helena e à queda de Tróia. Na Paris do século XIX, o termo ganhou adesão por referência à presença de estrangeiros nômades na cidade, aparentemente de etnia cigana, que por ela circulavam sem rumo certo e que inicialmente se julgava serem oriundos da região da Boêmia (situada na atual República Checa). Por analogia, o fenômeno deu origem a um movimento que viria a contagiar diversos artistas e intelectuais da época, tais como Charles Baudelaire, Gustave Coubert, Paul Verlaine, Rimbaud, Zola, Balzac, etc. Mas, segundo Murger, em todas as eras e em diferentes ambientes sempre existiram boêmios que circularam nos meios artísticos e literários. O próprio autor foi membro de um clube parisiense, auto-designado "Os bebedores de água", dada a escassez de dinheiro para consumirem vinho, a bebida tradicionalmente associada a estes meios.

3 Os estudos deste autor inspiraram-se na obra de Rabelais que retratou sagazmente o espírito satírico e burlesco das culturas populares da Europa do século $\mathrm{XV}$, olhando sobretudo o lado perverso e desconstrutivo da desordem, por oposição à moral dominante. $\mathrm{O}$ "corpo baixo" da impureza, da desproporção, está em oposição ao "corpo clássico", que é estético, bonito, simétrico. A cultura do carnavalesco invoca, por um lado, uma visão do mundo que remete para a possibilidade de um segundo nascimento a partir do espírito do riso e, por outro lado, enaltece a celebração festiva e a morfologia do "extra-ordinário" da cultura que corrói as instituições (Bakhtin, 1999). 
específicas da cultura acadêmica, quer para ajudar a traçar a diversidade de lógicas e comportamentos que compõem, ainda hoje, a população universitária da cidade.

É evidente nos dias que correm a enorme diversidade social entre a população universitária, inscrevendo-se a sua recomposição num processo de redefinição da estratificação social dos estudantes, dada a presença crescente de filhos das classes trabalhadoras e o aumento da oferta (e procura) dos cursos de pós-graduação (MACHADO et al., 2003; ESTANQUE e NUNES, 2003). Esta redefinição acompanha as atuais tendências de fluidez e de imprevisibilidade, inscrevendo-se, portanto, a vivência do presente em percursos e trajetórias pessoais cada vez mais incertos (NOWOTNY, 1994; LECCARDI, 2005). A própria idéia de projeto como antecipação de um futuro distante parece deparar-se com lógicas e subjetividades que a recusam, aparentemente por se inserirem em biografias de novo tipo, desvinculadas da noção de projeto e marcadas pela experimentação e pelo nomadismo. Segundo Melucci, os "nômades do presente" não perseguem um objetivo, antes avançam envoltos no provisório, rodeando lugares não conectados, passando por estações singulares das suas biografias e experimentando sucessivas aplicações de recursos e talentos em que o sucesso possível depende mais da própria mobilidade e procura do que da acomodação a uma meta previamente estabelecida (MELUCCI, 1998; BAUMAN e TESTER, 2001).

Numa época de riscos globais, como a presente, a incerteza ganhou um alcance universal e por isso deixou de ser entendida como governável a partir de uma qualquer racionalidade instrumental (LECCARDI e RUSPINI, 2005). A colonização do futuro projetado pelo presente, como se de um destino imponente se tratasse, tornou-se, nos planos individual, político e social num cenário pintado de tintas foscas. Uma idéia de futuro que a atual juventude, ao contrário das gerações precedentes, não consegue antever nem porventura deseja perscrutar . Porque a construção subjetiva do futuro, alimentada por experiências - próprias ou alheias - de frustração e descompensação, além de contornos obscuros e indefinidos, é rodeada de sentimentos difusos de alarme e de insegurança. Onde os "novos" movimentos sociais dos anos 60 e 70 viam a possibilidade 
de uma "terra prometida", as sociabilidades estudantis de inícios do século 21 desenham-se sob horizontes sombrios. As viragens ainda em curso no sistema universitário, na esfera política e no campo do emprego estão a marcar profundamente a atual geração, acentuando essas perplexidades.

As tendências de fragmentação, de individualização e desligamento social, de diluição dos velhos laços coletivos, da comunidade, da família etc., recolocam em novos moldes o processo - hoje amplamente aceito - de prolongamento do estatuto de "jovem", e consequente adiamento ou talvez recusa da condição de "adulto". Perante o panorama geral de divórcio dos cidadãos face ao sistema político democrático e de relativo esvaziamento da esfera pública, as possibilidades de ancoragem e de partilha coletiva das experiências vividas pelos jovens ao longo das suas trajetórias (em espaços de sociabilidade e estruturas organizadas, incluindo as instituições sociais e políticas) veem-se, assim, fortemente constrangidas. Por outro lado, quer as trajetórias fragmentadas, quer as metamorfoses que têm atingido os sistemas de emprego têm igualmente condicionado o aparente distanciamento dos jovens face aos movimentos sociais e associativos. As transições múltiplas deixaram de ser uma sucessão linear de etapas até à vida adulta, podendo as trajetórias biográficas tornar-se reversíveis, e em larga medida aleatórias, com milhares de jovens deambulando num vai-e-vem entre o sistema de ensino e o emprego ou "biscate"4 precário, numa espécie de "geração io-iô", como notou Pais (1998, 2001; PAIS et al., 2005).

Nestas circunstâncias, aquilo que comumente é tomado por individualismo, ainda que objetivamente se constate o afastamento ou indiferença dos jovens perante a ação política e associativa, não pode deixar de ser situado no seu devido contexto. A erosão de diversos marcos de referência que prevaleciam em gerações passadas, tanto na relação familiar e no percurso escolar como nos processos

4 É o que em Portugal se chama a um trabalho pontual e informal, que em geral é apenas uma tarefa (por exemplo, carregar ou descarregar produtos de um caminhão, reparar a canalização de uma casa etc.), muito embora possa ser efetuada por trabalhadores assalariados em regime permanente, numa outra empresa (neste caso seria um trabalho paralelo e informal). 
de socialização política repercutiu-se, naturalmente, nos planos cultural e ideológico que no passado não muito longínquo serviram de fio condutor a diversos setores estudantis, mais ou menos politizados, mais ou menos familiarizados com os meios culturais e as atmosferas de rebeldia acadêmica (BEBIANO \& CRUZEIRO, 2006; ESTANQUE \& BEBIANO, 2007; CARDINA, 2008).

\section{Coimbra - a boemia, a irreverência e a tradição}

Com mais de 700 anos de história, a Universidade de Coimbra (UC) foi, à semelhança de outras universidades europeias, uma instituição fundamental na formação das elites políticas, culturais e intelectuais do país. Para além dos conhecimentos transmitidos e da importância formal dos títulos acadêmicos, a frequência da mais antiga e prestigiada universidade do país era, por si só, uma garantia de prerrogativas distintivas e de um elevado status. $O$ peso da história, juntamente com a estreita imbricação da universidade na cidade - e a projeção desta como cidade universitária - contribuíram para construir ao longo do tempo uma identidade particular, fortemente devedora da presença estudantil e do saber acadêmico. Seria redundante recordar aqui os atributos históricos que fizeram da "Lusa Atenas" uma das cidades mais glorificadas e cantadas por poetas e escritores de todas as épocas. Camões, Eça, Garrett e Antero são apenas alguns dos nomes que nela deixaram as suas marcas, e que dão sentido à afirmação de Miguel Torga de que "não houve no nosso país revolução política ou movimento cultural que não encontrasse entre os estudantes de Coimbra apoio ou reflexo" (1950 apud FORTUNA \& PEIXOTO, 2002, p.28). Apesar da relação entre a cidade e a universidade nem sempre ter sido fácil - inclusive com momentos de grande tensão como aconteceu na sequência da destruição da "Alta" pelo governo de Salazar para nela instalar a "nova" universidade (TORGAL, 1999) -, a cidade continua a ver-se a si própria como "centro universitário" e os seus elementos identitários e representativos permanecem "intimamente ligados à mesma fonte: a Universidade” (FORTUNA e PEIXOTO, 2002: 29).

O imaginário das gerações que nos últimos anos passaram pela UC é, sem dúvida, povoado por valores e preocupações que 
nada têm a ver com as lutas dos anos 60. Se estas experiências de ativismo político já podem hoje ser incorporadas na própria "tradição" da academia local, dir-se-ia que elas foram nas últimas décadas remetidas para segundo plano, enquanto a tradição ritualista e festiva, cujas raízes situam-se num passado bem mais longínquo, ressurgiu com novo vigor após o intervalo que lhe foi imposto na sequência das lutas acadêmicas daquele período. Pode pensar-se que a irreverência política com que são conotados os movimentos estudantis choca com o ritualismo das tradições acadêmicas gerado num passado mais distante, sobretudo quando a universidade era um feudo exclusivo das elites. A história da Universidade de Coimbra é bem um exemplo de como uma tradição ritualista, reprodutora de hierarquias bem vincadas e de critérios seletivos fortemente elitistas pode conviver com formas de conduta e modos de vida marcados pela rebeldia e sentido transgressivo ${ }^{5}$.

O estilo de vida "boêmio" aplica-se sem dúvida ao meio estudantil de Coimbra, onde nunca faltaram exemplos e condições de florescimento de tais atmosferas, em especial devido à presença dos estudantes. Ao longo do século 19, sob o efeito das tendências europeias, as ideias progressistas e o debate público, se bem que muito circunscrito, tiveram algum eco no meio estudantil (LIMA, 1906) ${ }^{6}$. Diversos grupos reunidos regularmente em cafés, tabernas e ambientes de "tertúlia" - contagiados pelos ideais republicanos

5 Deve porém reconhecer-se que os processos de mudança das últimas décadas têm evidenciado uma crescente adaptação do ritualismo festivo aos ditames do mercantilismo consumista, com o correspondente afastamento ou indiferença da maioria dos estudantes face ao sentido de contestação coletiva de outras épocas. Mesmo a última onda de protestos com algum significado, a luta "anti-propinas" dos anos 90, já denunciava essa tendência, tendo ficado claro o relativo isolamento entre os setores mais ativos - notoriamente minoritários - e a generalidade da massa estudantil (DRAGO, 2004).

6 Esta monografia, de há cerca de 100 anos, mostra como a Coimbra da época era recordada não apenas pela universidade mas por tudo aquilo que a rodeia e, sobretudo, pela sua boemia e as suas tabernas, pela "lírica do choupal, a floresta divina, a paisagem vasta e melancólica do Penedo da Saudade, o horizonte largo e os ambientes rústicos e verdejantes do Penedo da Meditação, as ceias da Tia Camela, os debates e récitas do extinto Teatro Acadêmico, a Lapa dos Esteios, o Magrinho e os seus acepipes em cubículos de lona, e as iscas inexcedidas do inexcedível Julião...” (LIMA, 1906). 
e socialistas - travaram animados debates sobre os problemas da universidade e do país, estimulados pelo espírito crítico e progressista, perseguindo a idéia de modernidade que grassava na Europa de então e que a academia e o poder dos "lentes" rejeitavam ${ }^{7}$. Algumas figuras populares de épocas distintas - como o Agostinho Antunes, o Pantaleão, o Pad Zé, o Castelão de Almeida, o Taxeira, entre outros - tornaram-se lendárias precisamente devido à sua proximidade com o meio estudantil, sendo de certo modo apropriados e erigidos em ícones dessa "academia paralela" que animava os ambientes boêmios e contestatários de Coimbra (DUARTE, 2000). As "tertúlias" em cafés, tabernas e bordéis permitiam todo o tipo de misturas, incluindo diversas formas de expressão artística e musical, onde as baladas e o dedilhar de uma guitarra animavam ambientes de excesso, de consumo de álcool e de intercâmbio sexual. Mas, embora sendo espaços interclassistas, de diversidade e de encontro, eram restritos a um mundo masculino e marcado pela virilidade.

Embora as tradições incluídas na chamada praxe acadêmica ${ }^{8}$ revelem outro tipo de contornos, ela assume-se no contexto de Coimbra não só como uma importante dimensão da construção identitária do corpo estudantil, mas inclusive participa igualmente na estruturação das culturas de irreverência que acabo de referir. Se é certo que a relação entre a praxe, ou melhor, entre a atitude "praxista" e o ativismo cívico tem sido nos últimos tempos marcada

7 Foi neste ambiente que surgiram figuras de renome dos meios intelectuais portugueses. Alguns deles como Antero de Quental, José Fontana, Ramalho Ortigão, Oliveira Martins, Guerra Junqueiro, Teófilo Braga, Eça de Queirós, entres outros, integraram a chamada "geração de 70", que colocou em causa os paradigmas de conhecimento que dominavam a universidade (a chamada Questão Coimbrã), criticando abertamente a situação de atraso do país, discutindo e questionando inúmeros assuntos, da literatura à ciência e à política, quer no contexto de Coimbra, quer mais tarde em Lisboa com as Conferências do Casino, com as quais chamaram a atenção do país.

8 No Brasil esta noção é designada por "trote". Em sentido lato, o termo refere-se a todo o tipo de práticas e costumes que integram a tradição acadêmica. Porém, no seu uso comum é acima de tudo conotado com os rituais de iniciação, incluindo as brincadeiras, jogos, castigos (mais ou menos violentos e humilhantes) aplicados aos calouros (novatos, recém-chegados) pelos estudantes mais velhos. Ver abaixo as notas 8 e 9 , sobre a questão da violência em torno da praxe e as controvérsias que ela tem suscitado. 
por alguma tensão e conflito, ela foi também de complementaridade ao longo da história da academia (voltarei a este ponto mais adiante). Convém, por outro lado, não esquecer a componente lúdica, festiva e consumista que está contida nas iniciativas acadêmicas. A "Festa das Latas" (conhecida por "Latada") e a "Queima das Fitas"9 (em especial esta última) constituem momentos altos de excitação coletiva e adesão da massa estudantil. Caracterizadas nos últimos anos pela crescente força dos investimentos e interesses comerciais e pelo consumo abusivo de cerveja por parte dos jovens universitários, estas festas - que se prolongam por uma semana, no caso da "queima" - mobilizam milhares de jovens, muitos vindos de fora, e a generalidade dos estudantes de Coimbra, que a elas se dedicam intensamente.

É neste contexto que tanto os movimentos de protesto como a indiferença da juventude universitária de Coimbra deverão ser pensados na sua relação com o ritualismo e a tradição. A afirmação da identidade local - composta de múltiplos cruzamentos e ambivalências entre "universidade", "academia" e "cidade" - é, ela própria, constantemente readaptada através da permanente

9 Estes eventos incluem cada um deles um desfile de carros alegóricos, devidamente decorados com cores e motivos previamente preparados pelos estudantes das diferentes faculdades e cursos. No primeiro caso, trata-se de uma exibição pública dos novatos - ou "calouros" - que marcham a pé arrastando um conjunto de latas amarradas às pernas, em geral "atrelados" ao respectivo "padrinho" (um estudante mais "velho", ou seja, com estatuto superior na hierarquia do código da praxe e supostamente o seu protetor) e exibindo um aspecto ridículo, com pinturas na cara, chupetas na boca ou penicos na cabeça. A "parada" decorre no início de cada ano letivo, depois da semana de "recepção ao calouro", coincidindo com o período mais intenso de aplicação dos rituais praxistas. A queima das fitas tem lugar no início de Maio e inclui um conjunto de rituais como a dita "queima" das fitas (que são coloridas com as cores próprias de cada faculdade e fazem parte do traje acadêmico, sendo usadas juntamente com a pasta preta) que são então substituídas pelo "grelo" (fitas entrançadas), que passa a ser usado exclusivamente pelos estudantes que entram no último ano, os chamados "finalistas". Ao longo de uma semana de duração ocorrem diversas iniciativas, tais como o próprio desfile de carros, o baile de gala, a garraiada e uma sucessão de concertos musicais - que atualmente decorrem num local próprio designado por "queimódromo" -, em que cada um dos dias é dedicado a uma faculdade, isto entre diversas outras atividades de natureza lúdica, cultural ou desportiva. 


\section{releitura e reconstrução do seu tradicionalismo e da sua história.} Assim, as festas estudantis, o uso do traje e a praxe acadêmica ${ }^{10}$

10 No artigo 1ํ do Código da Praxe, esta é definida como "o conjunto de usos e costumes tradicionalmente existentes entre os estudantes da Universidade de Coimbra e os que forem decretados pelo Conselho de Veteranos". Mas, uma definição tão vaga exige algum complemento. Tratando-se de um fenômeno de grande atualidade e objeto de tantas controvérsias, veja-se a título de exemplo três visões distintas da praxe coimbrã (pelos próprios estudantes): 1. visão tradicional - "A Praxe Acadêmica é um conjunto de tradições geradas entre estudantes universitários e que há séculos vêm a ser transmitidas de geração em geração. É um modus vivendi característico dos estudantes e que enriquece a cultura lusitana com tradições criadas e desenvolvidas pelos que nos antecederam no uso da Capa e Batina. A Praxe Acadêmica é cultura herdada que nos compete a nós preservar e transmitir às próximas gerações. É preciso não esquecer o verdadeiro propósito e filosofia da Praxe Acadêmica. Esta serve para ajudar o recém-chegado a integrar-se no ambiente universitário, a criar amizades e a desenvolver laços de sólida camaradagem. É através da Praxe que o estudante desenvolve um profundo amor e orgulho pela instituição que frequenta, a sua segunda casa. Mas ela também ajuda o indivíduo a preparar-se para a futura vida profissional. Através das várias 'missões impossíveis' que o praxado tem de desempenhar, este vai-se tornando cada vez mais desinibido, habituando-se a improvisar em situações para as quais não estava preparado. A função educativa também está presente na Praxe Acadêmica. A sanção de rapar um caloiro quando apanhado na rua a partir de certas horas tem origem na intenção de o obrigar a estudar", in (http://pwp.netcabo.pt/qvidpraxis/praxe. html); 2. visão crítica - "A praxe tem-se vindo a desenvolver e a crescer sem controlo ou limite (...), em que já ninguém sabe como agir para retomar a 'boa e velha praxe'. (...) O aluno caloiro suporta a praxe porque tem a ideia de que num futuro próximo vai poder exercer esse mesmo 'poder' (...), é tudo uma questão de poder psicológico, o aluno mais velho sente e pensa que é mais que os novos alunos, pensa que é mais importante, e é através dessa exposição de força e poder que mostra aos outros o quanto ele vale no acto de praxar. Havia antigamente um costume na praxe em que o calouro tinha de ir arrumar a casa dos 'doutores', mas esse gesto foi tão criticado que hoje em dia é proibido nos códigos de praxe. As queixas de hoje são diferentes das queixas do passado, mas o que se verifica é que só mudaram os motivos pelos quais se queixa porque de resto continuam a queixar-se"; 3. visão moderada - "A Praxe não pode nunca ser sinónimo de humilhação ou de actos de violência barata levados a cabo por uns quantos frustrados que não sabem o que são as tradições acadêmicas e só usam um traje para se pavonearem na esperança de serem notados. São indivíduos destes os responsáveis pelo actual estado moribundo da verdadeira Praxe Acadêmica”, in http://www.regiaocentro.net/lugares/ coimbra/praxe/default.asp (...). E ainda na mesma linha "Nós (universitários) somos adultos, mas isso não quer dizer que tenhamos que ser apáticos, sem vida. Temos que manter a jovialidade e o espírito criativo que as crianças e os adolescentes por natureza possuem, mas, claro está, com a responsabilidade 
inscrevem-se naturalmente na identidade da academia e na sua história. A aura de prestígio da universidade e a centralidade que ocupou na sociedade portuguesa ao longo dos tempos não são alheios à sua estreita ligação ao poder eclesiástico, que a fundou e durante séculos a controlou. $\mathrm{O}$ poder acadêmico promoveu um conjunto de códigos e rituais tendentes a afirmar e reproduzir o estatuto de superioridade instituído pelo saber legítimo. Nessa medida, a simbologia distintiva que os estudantes reproduzem através dos seus inúmeros códigos, ritos e provas aplicadas aos mais novos, é alimentada pela instituição através dos seus próprios rituais de passagem que marcam os momentos de transição entre as diferentes etapas da carreira acadêmica. Além de celebrações públicas, assumem-se como actos de "sacralização" e ostentação, vincando desse modo as hierarquias de poder (FRIAS, 2003).

$\mathrm{O}$ traje acadêmico, com os seus diferentes adornos, cores, insígnias, mas também os títulos, os anéis de curso, a existência de padrinhos e tutores, etc., funcionam também como elementos classificativos e códigos de conduta que impõem diversas formas de demarcação social. A hierarquia e a necessidade de exibi-la simbolizaram ao longo da história a imagem dos setores privilegiados da sociedade e, por consequência, de dominação sobre os que deles dependem. A praxe aplicada aos novatos tem sido repetidamente objeto de controvérsia, sobretudo devido à violência que a acompanhou através dos tempos ${ }^{11}$. E justamente porque continua hoje

e com a ponderação que a nossa idade impõe. A praxe coimbrã é a única no país verdadeiramente democrática e regulamentada, com direitos e deveres a terem de ser respeitados por todos. Quem não concordar com ela, tem o direito a escolher se se submete ou não. Declarando-se anti-praxe, o estudante perde alguns direitos, mas não é ostracizado, não fica isolado dos seus colegas, nem perde a oportunidade de fazer amigos. Submetendo-se à praxe, o caloiro integrase muito mais depressa na vida de Coimbra e na sua nova etapa como estudante universitário" in <http://adsl.tvtel.pt/antipodas/txtpraxe.htm\#aac>.

11 A componente de violência sempre foi acompanhada de contestação dos "abusos". Assim, por exemplo, os castigos sobre os mais novos, à mistura com brigas por questões de honra e hierarquia, com os canelões e as investidas, ações que eram praticadas em Coimbra já no século XVIII, deram lugar a alguns tumultos e vozes críticas contra os que incomodavam os novatos, levando, por exemplo, o rei D. João V a decretar em 1727 a suspensão desses rituais, devido a mortais investidas contra os novatos perante a quase impunidade 
a ser um tema controverso, interessa perceber as suas contradições a fim de compreender os posicionamentos da população estudantil em relação às atividades da praxe (o que adiante procurarei mostrar). Assim, os julgamentos, as trupes, os rapanços, as touradas, onde os novatos eram o alvo da chacota, foram constantemente recriados e reinvestidos de lógicas próprias de cada contexto histórico. De resto, como lembra Frias (2003), tais práticas não são historicamente um exclusivo da universidade e dos colégios de ensino superior, antes fizeram parte da instituição escolar no seu conjunto, onde as coletividades jovens, celibatárias e masculinas promoviam e recriavam os seus códigos de conduta, submetendo os mais novos e recém chegados à autoridade dos mais velhos. Acresce que a violência foi, ao longo de muito tempo e sob diversas formas - como o uso da régua, da colher de pau ou do ponteiro - considerada como um ingrediente fundamental da educação e da instituição escolar no seu todo, ou seja, educação, civilidade, vigilância e disciplina estão intimamente ligados (FOUCAULT, 1977; CARON, 1999; ELIAS, 1989).

\section{As "repúblicas" estudantis e o comunitarismo "alternativo"}

As casas comunitárias de habitação estudantil - as conhecidas "repúblicas"12 - constituem espaços de convívio e formas particulares de autogestão que, não obstante o escasso número de estudantes que albergam e de estarem hoje em dia a sofrer uma crise de procura, pela sua história e significado mereceram ser contempladas no estudo que dá suporte empírico ao presente texto. Em diversos momentos de maior intensidade das lutas acadêmicas,

dos universitários: "Hey por bem e mando que todo e qualquer estudante que por obra ou palavra ofender a outros com o pretexto de novato, ainda que seja levemente, lhe sejam riscados os cursos" (Lamy, 1990).

12 Estas residências têm uma origem remota e difícil de situar com exatidão, mas supõe-se que as primeiras casas destinadas a ser ocupadas por grupos de estudantes terão sido construídas no início do século XIV pelo rei D. Dinis na zona de Almedina (Carreiro, 2002). Uma medida que deverá ter alguma relação com a existência das "Nações", igualmente residências coletivas de estudantes (e em alguns casos também dos seus mestres) que proliferaram na Idade Média pelos polos universitários europeus (Moulin, 1994). 
elas tiveram um papel preponderante e, como se mostrará adiante, continuam a ser um segmento que, apesar de minoritário, se mostra particularmente ativo e politizado, contrastando com a restante massa estudantil. Enquanto lugares de informalidade e de partilha comunitária por parte de jovens com instrução superior, elas terão propiciado a germinação, em diferentes épocas, de sentimentos de rebeldia e ideais de mudança e de progresso, em ruptura com as convenções vigentes e os poderes oficiais.

Embora atualmente os estudantes "repúblicos" revelem uma atitude crítica em relação ao exercício da praxe - e às próprias estruturas do associativismo estudantil -, os seus códigos de conduta e regras internas incluem também formas e ritos iniciáticos de cariz praxista, se bem que hoje com menor intensidade do que no passado $^{13}$. Ao longo do período salazarista as repúblicas, além de participarem activamente nas festividades e tradições estudantis, tiveram um papel decisivo nas lutas acadêmicas. O clima de festa e de "boemia", conjugou-se durante décadas com as atividades da praxe e a intervenção contestatária. Durante a década de 60 e em especial no período de viragem que ficou conhecido como "crise

13 As repúblicas e os seus ocupantes são atualmente conotados (pelo menos no imaginário do estudante comum) com uma certa imagem "intelectual", e também de "irresponsabilidade", onde é frequente o consumo de drogas e de álcool e onde os estudantes supostamente se divertem muito mas estudam pouco. Enfim, este rótulo de "marginalidade" que tem sido atribuído aos "repúplicos" obedece sem dúvida a um estereótipo bastante redutor da realidade. Como diante se verá, estas casas tiveram um importante papel na cultura acadêmica de Coimbra - nomeadamente no contexto das lutas estudantis dos anos 60 -, e procuram preservar a sua identidade forjada ao longo de gerações. Organizam anualmente os seus aniversários, conhecidos como os "centenários" nos quais são convidados a participar todos os antigos membros que passaram pela respectiva República. Os seus nomes, em geral envoltos numa carga irónica ou mesmo política, deixam antever um pouco destas colectividades estudantis: Real república dos Kágados; Real República Rapó-Taxo; Prá-Ky-Estão; Boa-Bay-Ela; Real República Baco; Ay-Ó-Linda; Real República dos Pyn-Guyns; Rosa Luxemburgo; Ninho dos Matulões; Real República Rás-te-Parta; Real República Spreit' Ó Furo; Real República Palácio da Loucura; Real República Trunfé Kopos; etc. Nos últimos anos a procura destas casas por parte dos estudantes tem diminuído e o 'movimento' geral das repúblicas tem vindo a perder impacto na academia; mas, por outro lado, como adiante se mostrará, é entre este segmento que parece mais forte a consciência crítica e a vontade de participação na esfera associativa. 
acadêmica de 69", os principais ativistas e líderes do movimento estudantil residiam em "repúblicas", tendo as suas paredes abrigado inúmeras reuniões clandestinas e iniciativas conspirativas e de resistência à política educativa e ao regime repressivo de Salazar. O Conselho de Repúblicas (CR) foi nessa época particularmente ativo na intervenção política, tanto no plano associativo local, integrando e promovendo listas que chegaram a vencer eleições para a Direção Geral da Associação Acadêmica de Coimbra (AAC), como a nível político mais geral na luta contra o Estado Novo (CRUZEIRO, 1989; NAMORADO, 1989; GARRIDO, 1996; BEBIANO, 2003; BEBIANO \& CRUZEIRO, 2006).

Com a "crise" de 1969, e sobretudo após o 17 de Abril desse ano (momento culminante da contestação em Coimbra), perante a greve estudantil e o encerramento da Universidade, dado o contexto da repressão que então foi exercida contra os dirigentes associativos e os estudantes, o Conselho de Repúblicas (CR) decretou o luto acadêmico - que se traduziu na interrupção das festas estudantis e do uso da capa e batina -, como forma de protesto contra o regime, decisão que formalmente não foi revogada até hoje. A tradição acadêmica foi então abandonada pela maioria dos estudantes universitários. O período de excepcional ativismo que se seguiu ao 25 de Abril de 1974 continuou a rejeitar a recuperação dos velhos rituais por serem então conotados com o regime deposto. Só no início dos anos 1980 a praxe e as festas acadêmicas de Coimbra começaram a ser reativadas, aliás num clima de grandes contradições político-ideológicas e de alguma conflitualidade. Apesar disso, os rituais acadêmicos - em especial o cortejo da Queima das Fitas e a Festa das Latas - foram plenamente relançados no início dos anos 80 do século passado.

Porém, os estudantes residentes nas repúblicas e o próprio CR mantiveram (regra geral) uma posição de recusa do chamado "espírito praxista", apesar de algumas delas terem aos poucos adotado uma atitude mais complacente e tolerante perante a praxe. Importa, portanto, sublinhar que, tal como a população estudantil se caracteriza pela sua pluralidade, também o universo das repúblicas é plural e heterogêneo. Existem atualmente repúblicas abertamente anti-praxe; outras que não permitem a praxe, mas admitem que os 
seus membros a façam no exterior da casa e aceitam o uso do traje acadêmico; outras que não tomam posição sobre o tema, dando liberdade aos seus membros; e existem ainda aquelas onde se segue escrupulosamente a tradição acadêmica.

Vale a pena uma breve nota sobre a questão feminina no contexto universitário. Na verdade, a presença hoje francamente majoritária de mulheres entre a população universitária parece evidenciar cada vez mais o claro contraste entre essa realidade e a predominância de um universo estudantil onde continua a prevalecer, em todos os domínios da vida acadêmica, a força do poder masculino. Isto, apesar de Coimbra e a sua universidade terem sido palco de importantes debates em torno do fenômeno, ou seja, de ter sido aqui desencadeado um dos primeiros movimentos de questionamento do lugar da mulher na sociedade, com a publicação no jornal acadêmico Via Latina, em 1961, da "Carta a uma jovem portuguesa", um texto anônimo que transcendeu o meio estudantil e o âmbito local. Apesar do peso demográfico das raparigas ("moças") 14 ter vindo a crescer de forma constante desde meados do século $20^{15}$ e da importância de figuras femininas entre os grupos de ativistas dos anos 60, a presença de mulheres nos lugares dirigentes das estruturas associativas tem sido escassa e na generalidade dos casos, mesmo quando elas estão presentes, continuam a ser os rapazes a monopolizar o protagonismo. Por outro lado, nos rituais acadêmicos e nas práticas da praxe persistem os códigos, as linguagens e os comportamentos marcados pela mesma masculinidade herdada do passado, sendo raros os exemplos de resistência e de denúncia dessa mesma lógica, de resto reproduzida e alimentada de igual modo por estudantes de ambos os sexos.

14 Importa referir que o termo "rapariga" não possui em Portugal a mesma conotação que encerra no Brasil. "Rapariga” é apenas o feminino de "rapaz". Neste caso refere-se a uma mulher jovem e solteira. Pelo contrário, uma "moça” (como se usa no Brasil) contém lá uma certa carga negativa; moça é mais entendida como a "criada", a empregada do café, etc.

15 Desde a década de 1950 a presença de raparigas na UC aumentou de $29 \%$ no ano de 1951-1952, para 40\% em 1961-1962, tendo atingido os 45\% em 1968-1969 e os 50\% em 1973-1974. Em 2004-2005 o peso das mulheres situou-se nos $54,4 \%$ (cf. Estanque \& Bebiano, 2007, p. 50 e 95). 


\section{Orientações perante a vida em sociedade}

Vale a pena referir alguns resultados empíricos de dois questionários ${ }^{16}$ aplicados aos estudantes da Universidade de Coimbra (UC), o primeiro em 2000 e o último em 2006. Através deles é possível analisar as atitudes e orientações da atual geração, quer quanto ao grau de individualismo ou envolvimento com sua comunidade, quer ainda quanto às suas representações acerca do significado das lutas e movimentos estudantis dos anos 60 . As orientações perante a vida social e pessoal são aqui abordadas recorrendo a uma tipologia que já foi utilizada em estudos anteriores sobre as atitudes estudantis (MACHADO et al., 1990; ESTANQUE \& NUNES, 2003) ${ }^{17}$.

No Quadro 1, abaixo, são comparados os resultados de dois questionários (o primeiro realizado em 2000, e o segundo em 2006), o que nos permite observar diversas evoluções no campo nas orienta-

16 Antes de apresentar e interpretar alguns desses dados, convém, no entanto, realçar que a presente análise se apoia não tanto nos dados quantitativos de per se, mas, antes, no acompanhamento e observação atenta dos comportamentos estudantis e também na vivência partilhada no ambiente acadêmico de Coimbra. Quer dentro das faculdades, quer sobretudo fora delas, enquanto decorreram os nossos projetos de pesquisa indicados no início, a equipe de pesquisadores procurou seguir os passos e misturar-se o mais possível nos ambientes frequentados por estudantes, designadamente nos espaços de lazer, nos rituais e festas, na esfera do consumo e ainda na circulação por muitas das casas comunitárias (as conhecidas "repúblicas" de Coimbra). Para além da observação directa - e, até certo ponto, "participante" - foram realizadas diversas entrevistas em profundidade a diversos líderes, ativistas, membros de Núcleos e da AAC, etc. (para uma análise mais completa e aprofundada ver ESTANQUE \& BEBIANO, 2007).

17 Este modelo fundamenta-se teoricamente na combinação de quatro princípios ou orientações subjetivas que podem articular-se de diferentes modos, segundo dois eixos: no primeiro contrapõem-se o princípio do investimento no indivíduo versus investimento no coletivo; e no segundo contrapõem-se o princípio do investimento no dia-a-dia versus o investimento no longo ou médio prazo. Uma vez cruzadas, estas dimensões dão lugar a quatro orientações subjetivas perante a vida e a sociedade: 1) um modelo de cotidiano autocentrado, ou seja, um modelo que dá primazia ao cotidiano e aos interesses individuais; 2) um modelo de projeto sociocentrado, ou seja, um modelo centrado num projeto futuro, com primazia do envolvimento social e do interesse colectivo; 3) um modelo de projeto autocentrado, ou seja, um modelo centrado num projeto futuro, com primazia do interesse individual; 4) um modelo de cotidiano sociocentrado, ou seja, um modelo que dá primazia ao cotidiano com envolvência social e colectiva. 
ções subjectivas dos estudantes ao longo desse período. Em primeiro lugar, fica claro que as atitudes estudantis reorientaram-se hoje mais num sentido individualista do que seis anos antes. Isto é, enquanto em 2000 a maioria dos inquiridos revelou uma preferência pelas opções sociocentradas, fosse no cotidiano $(33,3 \%)$ fosse no projeto $(32,7 \%)$, na atualidade essas tendências surgem em parte invertidas. Em geral, os resultados de 2006 continuam a revelar uma ligeira maioria de respostas de orientação "sociocentrada" $(50,2 \%$, somando as variantes "projeto" e "cotidiano") sobre as de orientação "autocentrada" (que somam $49,8 \%$ ), se bem que agora haja um quase equilíbrio em comparação com os resultados anteriores, que revelaram um claro desequilíbrio a favor das opções "sociocentradas" (66\% contra 34\%).

De fato, no último inquérito aumentaram significativamente as opções conotadas com atitudes autocentradas, seja na vertente "projeto" (35,7\% em 2006 contra 24,7\% em 2000), seja na vertente "cotidiano" (14\% em 2006 contra 9,4\% em 2000). No entanto, o projeto sociocentrado surge na atual geração como o segundo item mais escolhido $(28,1 \%), \log$ a seguir ao projeto autocentrado que é o primeiro $(35,7 \%)$, aparecendo em terceiro lugar a opção cotidiano sociocentrado $(22,1 \%)$ e em quarto lugar o cotidiano autocentrado (14\%). Isto significa que, apesar do aumento do número daqueles que revelam orientações autocentradas, estas só aparecem majoritárias (maioria relativa) na variante "projeto" e não na variante "cotidiano".

QUADRO 1. Atitudes perante a vida e a sociedade, segundo o sexo (\%)

\begin{tabular}{l|c|c|c|c|c|c|c|c}
\hline & \multicolumn{2}{|c|}{$\begin{array}{c}\text { Cotidiano } \\
\text { Autocentrado }\end{array}$} & \multicolumn{2}{c|}{$\begin{array}{c}\text { Cotidiano } \\
\text { Sociocentrado }\end{array}$} & \multicolumn{2}{c|}{$\begin{array}{c}\text { Projeto } \\
\text { Autocentrado }\end{array}$} & \multicolumn{2}{c}{$\begin{array}{c}\text { Projeto } \\
\text { Sociocentrado }\end{array}$} \\
\cline { 2 - 10 } & $\mathbf{2 0 0 0}$ & $\mathbf{2 0 0 6}$ & $\mathbf{2 0 0 0}$ & $\mathbf{2 0 0 6}$ & $\mathbf{2 0 0 0}$ & $\mathbf{2 0 0 6}$ & $\mathbf{2 0 0 0}$ & $\mathbf{2 0 0 6}$ \\
\hline Mulheres & 7,4 & 10,7 & $\mathbf{3 6 , 2}$ & 24,9 & 22,0 & $\mathbf{3 8 , 4}$ & 34,4 & 26,1 \\
Homens & 13,1 & 20,5 & 27,8 & 17,1 & 27,8 & 30,7 & 31,4 & 31,7 \\
\hline Total & 9,3 & 14,1 & 33,4 & 22,1 & 23,9 & 35,7 & 33,4 & 28,1 \\
\hline
\end{tabular}

Fonte: Inquéritos aos estudantes da UC (2000 e 2006), Centro de Estudos Sociais.

Quanto à distribuição segundo o sexo, a comparação apresenta igualmente resultados interessantes. Em 2000 as mulheres eram majoritárias em itens como projeto sociocentrado $(34,4 \% \mathrm{Ms}$ contra $31,4 \% \mathrm{Hs})$ e cotidiano sociocentrado $(36,2 \%$ contra $27,8 \%)$ e eram 
claramente minoritárias nos dois restantes tipos de representações sociais, quer no projeto autocentrado $(22 \%$ Ms contra $27,8 \% \mathrm{Hs})$ quer no cotidiano autocentrado $(7,4 \% \mathrm{Ms}$ contra $13,1 \% \mathrm{Hs})$. Isto permitenos concluir que, segundo os resultados do primeiro estudo, se deveu sobretudo às mulheres o fato de a maioria dos inquiridos ter revelado uma maior preferência por subjetividades com maior envolvência social e no coletivo.

Os resultados de 2006 evidenciam uma certa inversão. No caso da opção projeto sociocentrado, o setor feminino passou a estar em minoria, e a uma distância significativa do sexo oposto $(26,1 \%$ Ms, $31,7 \% \mathrm{Hs})$, enquanto antes acontecia o contrário. O oposto do que acontece no item projeto autocentrado $(38,4 \% \mathrm{Ms}, 30,7 \% \mathrm{Hs})$ e no cotidiano sociocentrado $(24,9 \% \mathrm{Ms}, 17,1 \% \mathrm{Hs})$ onde as mulheres aparecem em clara maioria. Quer no cotidiano autocentrado $(10,7 \%$ Ms, $20,5 \% \mathrm{Hs})$, quer no projeto sociocentrado $(26,1 \% \mathrm{Ms}, 31,7 \% \mathrm{Hs})$ são os rapazes que estão em maioria, tendo neste último caso aumentado a diferença a favor das moças, sobretudo à custa da redução da adesão delas a esta opção.

Daqui se conclui que ao longo deste período os estudantes parecem ter desinvestido nas orientações "sociocentradas" - em especial as estudantes - e passado a investir mais nas orientações "autocentradas", muito embora no caso dos rapazes se mantenha uma maior aposta no projeto sociocentrado (que se reforçou ligeiramente). No caso do cotidiano autocentrado nota-se um aumento muito significativo de ambos os sexos, mas sobretudo entre os rapazes, enquanto no projeto sociocentrado eles mantêm essa orientação, ao passo que elas diminuem claramente. Trata-se neste caso, claramente, de um efeito que deriva do aumento das dificuldades no acesso ao emprego. Ou seja, a pressão do mercado de trabalho e o desemprego de licenciados parecem resultar num maior investimento na defesa do interesse individual, tanto no imediato como no médio ou longo prazo. Por outro lado, a persistência dos rapazes no projeto sociocentrado prende-se aparentemente com a sua participação mais assídua nas estruturas organizativas da sociedade e no movimento estudantil (como adiante se verá), o que sem dúvida contribui para reforçar o sentido de partilha e o envolvimento social dos jovens na construção do futuro coletivo. 
Ainda a este propósito, convém assinalar as diferenças entre os estudantes das repúblicas e os restantes. Tanto a tradição e a memória histórica que está intimamente associada a estas casas "comunitárias", como a própria experiência vivida em coletividade conferem-lhes características específicas. De fato, entre a minoria de estudantes "repúblicos" e os restantes são patentes os contrastes nas respectivas atitudes, ou seja, a preferência por orientações sociocentradas é muito evidente no caso dos estudantes das repúblicas, enquanto que o chamado projeto autocentrado (que, como já se viu, recolhe a maioria de respostas da totalidade da amostra) é rejeitado quase em absoluto por este segmento da população estudantil. Aparentemente, os "repúblicos" são mais sensíveis ao envolvimento com os outros, o que se prende com o fato de no interior das casas em que vivem prevalecer uma cultura de partilha e corresponsabilização na divisão das tarefas quotidianas no espaço da habitação, mas esta sensibilidade menos individualista não será alheia a outros fatores socioculturais.

Para além das conotações que ligam o ambiente das repúblicas ao passado de luta do movimento estudantil coimbrão, subsiste o tradicional espírito de tertúlia, caracterizado pela presença de uma cultura de boemia na qual se combinam o sentido de irreverência e o estilo de vida "alternativo" ou supostamente "vanguardista", quer no plano político quer no plano estético e dos consumos culturais. Com todas as suas tonalidades e sem esquecer a heterogeneidade que desde sempre acompanhou a vida nas repúblicas, esta imagem subsiste entre a atual geração de estudantes. Muitos lançam sobre este setor minoritário um olhar de reprovação ou desconfiança, associando-os a irresponsabilidade, excesso de consumo de álcool e fraco aproveitamento escolar. Seja como for, o modo de vida e as orientações subjetivas desta minoria refletem-se em atitudes e práticas notoriamente distintas, como pode verificar-se noutros resultados do estudo.

\section{Memória e representações dos anos 60}

Importa por fim atentar nas opiniões recolhidas acerca dos movimentos estudantis dos anos 60 . As referências ao passado de luta estudantil desse período continuam a ser uma constante no discurso 
dos dirigentes associativos, muito embora as ideias partilhadas pela atual geração evidenciem a memória esbatida e as ambiguidades acerca dos acontecimentos de há quarenta anos. Os resultados aqui expressos revelam uma certa aproximação das opiniões de ambos os sexos, mas igualmente algumas diferenças evidentes. A importância desses movimentos na formação dos atuais quadros e dirigentes políticos é bem mais reconhecida pelos rapazes do que pelas raparigas (46,6\% Ms, $60,1 \% \mathrm{Hs}$ ) e o mesmo se passa com a ideia de que nada têm a ver com a atualidade e são sobrevalorizados (14,9\% Ms, $20 \% \mathrm{Hs})$.

QUADRO 2. Opinião sobre os movimentos estudantis dos anos 60 - comparação entre os estudantes das Repúblicas e os outros, e segundo o sexo (\%)"

\begin{tabular}{|c|c|c|c|c|c|}
\hline \multirow{2}{*}{ Opiniões/ afirmações } & \multicolumn{2}{|c|}{ Sexo } & \multicolumn{2}{|c|}{ Compar. c/ Repúblicas } & \multirow{2}{*}{ Total } \\
\hline & Ms & Hs & Repúblicas & Outros & \\
\hline $\begin{array}{l}\text { 1. Foram importantes para a democra- } \\
\text { tização do país }\end{array}$ & 74,3 & 75,7 & 66,0 & 75,1 & 74,8 \\
\hline $\begin{array}{l}\text { 2. Trouxeram grandes mudanças ao } \\
\text { funcionamento da Universidade }\end{array}$ & 64,9 & 61,5 & 60,0 & 63,8 & 63,7 \\
\hline $\begin{array}{l}\text { 3. Tiveram mais a ver com a política do } \\
\text { que com os interesses estudantis }\end{array}$ & 33,7 & 35,1 & 23,2 & 34,4 & 34,2 \\
\hline $\begin{array}{l}\text { 4. Nada têm a ver com a actualidade e } \\
\text { são sobrevalorizados }\end{array}$ & 14,9 & 20,0 & 14,6 & 16,7 & 16,7 \\
\hline $\begin{array}{l}\text { 5. Exprimiram o elitismo da universi- } \\
\text { dade em relação ao resto da sociedade }\end{array}$ & 12,8 & 18,7 & 17,9 & 14,9 & 14,9 \\
\hline $\begin{array}{l}\text { 6. Têm influência nas atuais movimen- } \\
\text { tações estudantis }\end{array}$ & 38,8 & 36,8 & 32,1 & 38,3 & 38,1 \\
\hline $\begin{array}{l}\text { 7. Foram importantes na formação dos } \\
\text { atuais quadros e dirigentes políticos }\end{array}$ & 46,6 & 60,1 & 57,1 & 51,4 & 51,3 \\
\hline $\begin{array}{l}\text { 8. Criaram laços de partilha e solidar. } \\
\text { geracional entre os estudantes }\end{array}$ & 41,8 & 40,5 & 41,0 & 41,3 & 41,4 \\
\hline
\end{tabular}

* As percentagens referem-se às respostas concordantes com estas afirmações, isto é, correspondem ao somatório das respostas $4+5$, num leque de cinco opções (entre $1=$ discorda totalmente, e 5 = concorda totalmente).

Muito provavelmente estes resultados devem-se ao fato de, regra geral, os rapazes continuarem a ocupar um maior protagonis- 
mo no plano político e associativo, o que por sua vez corresponde a uma mais notória politização do sector masculino. Mesmo quando se trata de opiniões muito minoritárias, a diferença relativa das respostas, mostra como os rapazes são sempre mais radicais e extremados do que as raparigas.

Na comparação com os estudantes das repúblicas, apesar de igualmente espelhar uma relativa proximidade de posições, parece notar-se a este respeito uma atitude entre os "repúblicos" ilustrativa de um menor "entusiasmo" do que poderia esperar-se, relativamente às lutas acadêmicas daquela que é geralmente considerada a "década de ouro" dos novos movimentos sociais e onde, como se viu, este segmento teve grande protagonismo. Embora a maioria dos estudantes das repúblicas também enalteçam o papel dos movimentos estudantis daquela geração, fazem-no em menor percentagem do que os seus colegas "não repúblicos". Isso acontece por exemplo no caso da opinião de que eles foram importantes para a democratização do país (66\% dos "repúblicos" contra $75,1 \%$ dos outros); quanto à consideração de que as lutas desse período trouxeram grandes mudanças ao funcionamento da Universidade (60\% Rs, 63,8\% outrs); e ainda no caso da opinião de que as mesmas têm influência nas atuais movimentações estudantis (32,1\% Rs, 38,3\% outros). A minoria de estudantes das repúblicas também considera, de forma mais vincada do que os restantes, que os movimentos acadêmicos dos anos 60 foram importantes na formação dos atuais quadros e dirigentes políticos $(57,1 \%$ Rs, 51,4\% outrs); mas, por outro lado, são igualmente mais firmes na defesa da ideia de que exprimiram o elitismo da Universidade em relação à sociedade, apesar de se tratar também aqui de uma ínfima minoria (17,9\% Rs, $14,9 \%$ outrs).

Tendo em conta a tradicional ligação das comunidades estudantis das repúblicas aos momentos mais intensos da luta acadêmica (dos anos 60, sobretudo), poderia esperar-se que isso se traduzisse numa atitude mais "glorificadora" dessas experiências. Porém, os resultados não revelam exatamente isso. Uma possível hipótese explicativa é a seguinte: existe uma percepção, que parece estar a insinuar-se entre os estudantes das casas comunitárias, de que o resultado das lutas daquela época não correspondeu às expectativas "emancipatórias" das anteriores gerações, e aparentemente, 
também não responde às necessidades da atual geração. Quando os "repúblicos" reconhecem os impactos dessas lutas na formação da atual "classe política" estão, porventura, a querer dizer-nos que essa influência não foi tão relevante quanto seria de esperar, visto que, como sabemos, o seu ponto de vista sobre os atuais "políticos" se caracteriza pelo distanciamento crítico. Além disso, como as Repúblicas de hoje estão longe de possuir a mesma influência das daquela época - ou sequer a mesma presença física na cidade estudantil -, sendo notória a sua incapacidade de tocar a massa estudantil mais geral, compreende-se o sentimento difuso (que estes resultados parecem indicar) de que esse passado e as suas promessas se esgotaram nos seus próprios limites, daí resultando a convicção de que, na presente conjuntura, os problemas sociais e estudantis exigem outro tipo de respostas. É certo que - por razões do próprio contexto político - nos anos 60 as condições eram bem diferentes, sendo a ação coletiva objeto de repressão policial mas ao mesmo tempo suscitando maior união entre as diferentes correntes e setores de estudantes ${ }^{18}$. Todavia, o fato de tais condições serem hoje impossíveis de realizar, do ponto de vista do setor mais radical dos "repúblicos", pode contribuir para ampliar esse sentimento de demarcação, que porventura é corolário da percepção de uma necessidade de desenhar novas rupturas e formas de luta, que pouco têm a ver com esse passado.

\section{Conclusão}

Como acabei de mostrar, os resultados do inquérito revelam uma escassa participação dos estudantes nas atividades associativas e também nos atos eleitorais da Associação de Estudantes (AAC). Esta situação é sem dúvida expressão das tendências mais gerais

18 Apesar da diversidade de posturas - também nessa época - e da conscientização política ser escassa e restrita a uma minoria; apesar das dificuldades e do clima repressivo, ou por isso mesmo, a vontade de resistir e de lutar contra um adversário bem identificado (o poder político e universitário que negava a democracia e os direitos dos estudantes) favoreceu uma maior sintonia entre as vanguardas organizadas e a massa estudantil, em particular nos momentos mais intensos de conflitualidade. 
das democracias ocidentais onde se assiste a um crescente divórcio entre a ação política e os cidadãos.

Assim, é necessário atender a que as formas tradicionais de intervenção pública e as modalidades de ativismo político que vigoraram ao longo da segunda metade do século 20 se encontram em profunda transformação. Por um lado, assistiu-se à emergência de todo um conjunto de novas dinâmicas e formas de mobilidade social e territorial, à intensificação dos fluxos globais de todos os tipos, à presença crescente das novas tecnologias da informação, ao aumento da concentração urbana etc., o que conduziu a mudanças drásticas nos modos de vida em sociedade e a uma maior individualização das relações sociais.

No caso da Universidade de Coimbra, os processos de massificação, o cotidiano da vida estudantil e a crescente feminização alteraram as atmosferas da cidade e os núcleos em que germinaram as sociabilidades alternativas são, hoje, muito escassos. Em primeiro lugar, os estudantes na sua maioria (que são sobretudo oriundos da região Centro, $70 \%$ e do distrito de Coimbra, 35\%), ou habitam com os pais na cidade ou visitam as suas famílias semanalmente, saindo muitas vezes à sexta-feira e regressando à segunda-feira. Isto retira logo algum sentido à capacidade de reforço das identidades de grupo e à promoção de atividades de índole cultural e associativa.

Em segundo lugar, o acentuar da evasão regular/ semanal para fora da cidade prende-se também com a maior presença de filhos da classe trabalhadora e de raparigas. Ou seja, perante esta composição das origens sociais, dados os constrangimentos financeiros que de se adivinham, tende a existir uma maior pressão da família no sentido da conclusão do curso dos filhos, com a maior brevidade possível, tendo em vista alcançar rapidamente uma posição no mercado de trabalho. Além disso, não só a família e o acesso ao mercado de trabalho são hoje em dia os principais fatores de preocupação apontados pelos estudantes, como o setor feminino revela em geral uma maior dedicação à família, recordando que elas estão em número significativo sobretudo entre o segmento dos que são filhos de trabalhadores não qualificados, cerca de 31\% (ESTANQUE \& NUNES, 2003).

Em terceiro lugar, o fenômeno da feminização introduziu uma importante dissonância na cultura estudantil de Coimbra, 
uma vez que a tradição acadêmica é fortemente masculinizada. Os rituais festivos, os cortejos, as brincadeiras da praxe, as próprias canções associadas ao simbolismo da universidade são todos eles imbuídos de valores patriarcais e de atitudes onde persiste algum marialvismo. Nuns casos a violência (simbólica ou física), noutros as práticas sexistas tendem ainda a relegar as raparigas para um estatuto secundário em relação aos rapazes. Por exemplo, não é permitido às mulheres cantarem o "fado" ${ }^{19}$ de Coimbra (não sendo proibido, há no entanto uma resistência da parte dos mais acérrimos defensores da tradição); os dirigentes associativos e os ativistas são majoritariamente rapazes; mesmo as jovens que ocupam posições na estrutura dirigente da associação ou nos "núcleos" de curso das faculdades, os pelouros que lhes são atribuídos são os de pendor mais "feminino" (de acordo com o cânone tradicional); na Direção Geral, as "meninas" (além de serem minoritárias) surgem sempre na segunda ou na terceira fila nas diversas cerimônias oficiais onde a associação está representada. Em contrapartida, e pela mesma ordem de razões, algumas das (poucas) iniciativas de crítica à praxe acadêmica e ao machismo de que a tradição acadêmica está imbuída, foram, nos últimos tempos, dinamizadas por núcleos de mulheres (nomeadamente as repúblicas femininas como a "Rosa Luxemburgo" ou as "Marias do Loureiro"), contribuindo para sensibilizar algumas consciências a este respeito. Tal contestação, porém, não tem tido grande continuidade e ultimamente, apenas em situações muito pontuais, como foi o caso do lançamento de um novo disco de fados de Coimbra cantados por uma mulher (CRISTINA CRUZ, Coimbra Menina do Meu Olhar, Aeminium Records, 2006), a problemática das relações de género na UC surge como tema de debate público.

No momento em que a universidade se debate com um processo geral de reestruturação - na sequência do processo de

19 Os puristas preferem em geral falar de "canção de Coimbra”, já que o "fado" é típico de Lisboa, e é na capital que tem as suas raízes. Trata-se de músicas com acompanhamento à guitarra e viola, cantadas exclusivamente por estudantes ou ex-estudantes de Coimbra, e que inicialmente eram cantadas nas "serenatas", versos de amor dedicados a uma "amada", a forma como o estudante que possuía dotes musicais (homem, naturalmente) costumava seduzir o seu objeto de amor, acompanhado de alguns amigos, fazendo-se ouvir durante a noite, a partir da rua em frente à residência de sua pretendida. 
Bolonha - é difícil avançar prognósticos acerca dos impactos da mudança em curso, quer na esfera do ritualismo quer no que respeita às actividades associativas e ao movimento estudantil. As alterações ao regime jurídico do ensino superior já decididas pelo governo, em especial o fato de os estudantes perderem praticamente toda a representatividade que detinham nos órgãos de gestão da universidade e das faculdades, só recentemente deram lugar à readaptação dos estatutos das instituições universitárias, prevendo-se para breve um processo semelhante nas faculdades.

Aparentemente, este novo cenário poderia favorecer o desencadear de novas ações de contestação. Porém, o panorama que hoje se vive em Portugal entre o movimento estudantil é marcado pela indiferença. A juventude universitária é pouco politizada e os setores que o são tendem a fechar-se no seu ciclo restrito e escudamse num discurso radical e por vezes dogmático - por exemplo, há sinais de que a minoria dos que vivem nas repúblicas, apesar da sua postura de esquerda, mostram acima de tudo um evidente desprezo pela "massa" dos estudantes - deixando transparecer o seu "ethos" elitista e, portanto, a falta de capacidade ou de vontade para uma efetiva ligação aos problemas do estudante comum.

Por seu lado as estruturas associativas são conotadas pela maioria dos estudantes com o jogo político e com estratégias (inclusive pessoais) tendentes a servir-se do protagonismo que os cargos dirigentes sempre propiciam em benefício próprio. $\mathrm{O}$ fato de muitos ex-dirigentes ocuparem atualmente cargos políticos ou profissionais de relevo fornece também um motivo acrescido para que grande parte da juventude universitária olhe com ceticismo para os seus dirigentes ou simplesmente não participe em qualquer actividade associativa, nem mesmo nos atos eleitorais. No atual contexto de mudança no funcionamento do sistema universitário e de recomposição da população estudantil de Coimbra, a construção das sociabilidades estudantis e a sua ligação à cidade alteram-se substancialmente.

A maior proximidade geográfica dos estudantes em relação às suas terras de origem, ao contrário do que poderia esperar-se, não está a facilitar a fixação da população estudantil nem parece contribuir para reforçar a identidade coletiva dos estudantes na relação 
com espaço da cidade e menos ainda através do seu contributo ativo na dinamização da actividade cultural local (ela própria bastante incipiente, diga-se). Com efeito, a maior facilidade de transportes aliada ao fato dos estudantes serem hoje mais dependentes do apoio financeiro das famílias (muitas delas de classe-média/ trabalhadora), são fatores que favorecem o aumento dos fluxos pendulares de fim de semana, levando muitos estudantes a sair à sexta-feira e a regressar à segunda-feira, reduzindo-se assim o tempo de estada na cidade. Assim, as vivências e sociabilidades da juventude estudantil no espaço urbano passaram a ser mais frágeis e voláteis, contribuindo para esbater a sua identificação com a cidade de Coimbra, tornada para eles um lugar de passagem.

Tudo isso somado às condicionantes sociais mais gerais, onde prevalece o individualismo, o desinteresse pelo conhecimento e pela atividade cultural, a indiferença perante a vida pública, pelo associativismo e o exercício da cidadania, etc., apresenta-nos um conjunto de fatores justificativos da fragilidade do movimento estudantil na Universidade de Coimbra. Por isso, se a universidade e a população estudantil continuam a ser as principais referências da identidade coimbrã, faria sentido que as instituições locais - em especial o poder municipal e as autoridades acadêmicas - prestassem maior atenção e mostrassem mais dinamismo face às tendências preocupantes que hoje se desenham neste campo, por forma a procurar invertê-las. Para compreender a realidade atual de Coimbra importa ter presente o significado e o prestígio granjeados no passado, mas importa também, se queremos fazer jus a esse prestígio, evitar que essa tradição seja confundida com uma peça de museu. É inegável a importância fulcral que representa o envolvimento e a fixação dos estudantes (e também os licenciados e pós-graduados) na vida cultural e econômica da cidade, bem como o potencial contributo para a dinamização, desenvolvimento e projeção nacional e internacional daquela que (justamente pela importância da sua universidade) se tornou conhecida como a "Lusa Atenas". 


\section{Referências}

BAKHTIN, M. A Cultura Popular na Idade Média e no Renascimento: O contexto de François Rabelais. São Paulo/ Brasília: Editora UnB/ Hucitec, 1999.

BAUMAN, Z. \& TESTER, K. Conversations with Zygmunt Bauman. Cambridge: Polity Press, 2001.

BEBIANO, R. Cidade e Memória na Intervenção Estudantil em Coimbra. Revista Crítica de Ciências Sociais, 66, 151-163, 2003.

BEBIANO, R. \& CRUZEIRO, M. Anos Inquietos. Vozes do Movimento Estudantil em Coimbra [1961-1974]. Porto: Afrontamento, 2006.

BECK, U. Un Nuevo Mundo Feliz: la precaridad del trabajo en la era de la globalización. Barcelona: Paidós, 2000.

. Cosmopolitan Visions. Cambridge: Polity Press, 2006.

BOLTANSKI, L. \& CHIAPELLO, È. Le Nouvelle Esprit du Capitalisme. Paris: Gallimard, 2001.

BOURDIEU, P. Questions de Sociologue. Paris: Minuit, 1984.

CARDINA, M. A Tradição da Contestação. Coimbra: Angelus Novus, 2008.

CARDOSO, I. A geração dos anos de 1960: o peso de uma herança. Tempo Social - Revista de Sociologia da USP, 2005.

CARON, J-C. A l'École de la Violence. Châtiments et Sevices dans l'Institution Scolaire au XIXème Siècle. Paris: Aubier, 1999.

CARREIRO, T.M.A. Viver numa República de Estudantes de Coimbra - Real República Palácio da Loucura (1960-70). Faculdade de Ciências Sociais e Humanas da Universidade Nova de Lisboa (Tese de mestrado), 2002.

COHEN, J.L. \& ARATO, A. Civil Society and Political Theory. Cambridge: MIT Press, 1992.

CRUZEIRO, C. Coimbra, 1969. A crise acadêmica, o debate das ideias e a prática, ontem e hoje. Porto: Afrontamento, 1989.

DELICADO, A. A solidariedade como valor social no Portugal contemporâneo. In VALA, J.; CABRAL, M.V. \& RAMOS, A. (Orgs.), 
Valores Sociais: mudança e contrastes em Portugal e na Europa. Lisboa: ICS, 199-256, 2003.

DRAGO, A. Agitar antes de ousar: o movimento estudantil “antipropinas". Porto: Afrontamento, 2004.

DUARTE, M. A taberna e a boémia coimbrã - Práticas de lazer dos estudantes de Coimbra. Coimbra: FEUC (Tese de Licenciatura, mimeo), 2000.

EAGLETON, T. Ideology. London: Verso, 1991.

EDER, K. The New Politics of Class - Social Movements and Cultural Dynamics in Advanced Societies. London: Sage, 1993.

ELIAS, N. O processo civilizacional. Lisboa: D. Quixote, 1989.

ESTANQUE, E. "A questão social e a democracia no início do século XXI - Participação cívica, desigualdades sociais e sindicalismo", Finisterra, 55/56/57, 77-9, 2006.

ESTANQUE, E. \& BEBIANO, R. Do activismo à indiferença. Movimentos estudantis em Coimbra. Lisboa: Instituto de Ciências Sociais, 2007.

ESTANQUE, E. \& NUNES, J.A. Dilemas e desafios da Universidade: Recomposição social e expectativas dos estudantes na Universidade de Coimbra. Revista Crítica de Ciências Sociais, 2003.

EYERMAN, R \& JAMISON. Social Movements - A Cognitive Approach. Cambridge: Cambridge University, 1991.

FORTUNA, C. \& PEIXOTO, P. A recriação e reprodução de representações no processo de transformação das paisagens urbanas de algumas cidades portuguesas. In: FORTUNA, C. \& SILVA, A.S. (Orgs.), Projeto e circunstância. Culturas urbanas em Portugal. Porto: Afrontamento, 2002.

FOUCAULT, M. Vigiar e punir. Petrópolis: Editorial Vozes, 1977.

FRIAS, A. Praxe acadêmica e culturas universitárias em Coimbra. Revista Crítica de Ciências Sociais, 2003.

GARRIDO, Á. Movimento estudantil e crise do Estado Novo. Coimbra, 1962. Coimbra: Minerva, 1996.

HOLZMANN, L. \& PADRÓS, E. 1968 Contestação e Utopia. Porto Alegre: UFRGS, 2003. 
LAMY, A.S. A Academia de Coimbra, 1537-1990. Lisboa: Rei dos Livros, 1990.

LECCARDI, C. \& RUSPINI, E. (Orgs.) A New Youth?. Aldershot: Ashgate, 2005.

LECCARDI, C. Por um novo significado do futuro: mudança social, jovens e tempo. Tempo Social - Revista de Sociologia da USP, 2005.

LIMA, J.L.A. Meio século de vida coimbrã. Ilustração Portuguesa. 22, 685, 1906.

MACHADO, F.L. et al. Classes sociais e estudantes universitários: origens, oportunidades e orientações. Revista Crítica de Ciências Sociais, 66, 2003.

MACHADO, F.L. et al., Identidades e orientações dos estudantes: classes, convergências, especificidades. Revista Crítica de Ciências Sociais, 27/28, 1990.

MANHEIM, K. Essays on the Sociology of Knowledge. London: Routledge and Kegan Paul, 1952.

MELUCCI, A. Challenging Codes. Collective action in the information age. Cambridge: Cambridge University Press, 1996.

MELUCCI, A. Nomads of the Present. London: Hutchinson, 1998.

MOULIN, L. A Vida Quotidiana dos Estudantes na Idade Média. Lisboa: Livros do Brasil, 1994.

MURGER, H. Scenes De La Boheme. London: Vizetelly \& Co, 1888. Disponível em: http://home.swbell.net/worchel/contents.htm (Acedido em: 13/08/2008).

NAMORADO, R., Para uma Universidade Nova - Crónica da Crise de 69 em Coimbra. Revista Crítica de Ciências Sociais, 27/28, 1989.

NOWOTNY, H. Time: the Modern and Post Modern Experience. Cambridge: Polity Press, 1994.

PAIS, J.M. A construção sociológica da juventude. Análise Social, 105/106, 139-165, 1990.

. Gerações e valores na sociedade portuguesa contemporânea.

Lisboa: Instituto de Ciências Sociais, 1998. 
. Ganchos, tachos e biscates: jovens, trabalho e futuro. Lisboa: Âmbar, 2001.

PAIS, J.M.; CAIRNS, D. \& PAPPÁMIKAIL, L. Jovens europeus: retrato da diversidade. Tempo Social, 17(2), 2005.

POLLOCK, G. Contingent identities. Young, 10, 2002.

RIBEIRO, G.L. Política Cibercultural: ativismo político à distância na comunidade transnacional imaginada-virtual. In ALVEREZ, S; DAGNINO, E. \& ESCOBAR, A. Cultura e Política nos Movimentos Sociais Latino-Americanos. Belo Horizonte: Editora UFMG.

SANTOS, B.S. A Universidade do século XXI: para uma reforma democrática e emancipatória da universidade. São Paulo: Cortez, 2004.

2005.

. Fórum Social Mundial: Manual de Uso. Porto: Afrontamento,

. A Gramática do Tempo: para uma nova cultura política. Porto: Afrontamento, 2006.

TORGAL, L.R. A Universidade e o Estado Novo. Coimbra: Minerva, 1999.

TOURAINE, A. An Introduction to the Study of Social Movements. Social Research, 52(4), 1985.

. Na fronteira dos movimentos sociais. Sociedade e Estado, 21(1), 2006.

\begin{abstract}
Youth, bohemia and social movements: student cultures and struggles at the University of Coimbra.

This text takes up some of its author's recent work on student youth in Coimbra. Centered around the Coimbra university environment and an academic tradition of over 700 years of history, its primary objective is to question some current tendencies among university students, through the acute gaze of a professor who has been involved in the student and daily life of the city for over 20 years. It attempts to identify subjectivities, participatory logics and attitudes of indifference/demarcation among different segments of the student population. More than a phenomenological register of daily life in academia, the text is meant to capture experiences
\end{abstract}


of the past and the ways in which they can (or cannot) be appropriated by the current generation of students. On the other hand, the profound changes of recent decades, both in Portugal itself and within the Portuguese higher educational system, have reoriented behavior, expectations and forms of action of the current university population, encouraging its distancing with regard to this past and a 'forgetting' of the meaning of the social movements which during the 1960s contributed to undermining the Salazar and Caetano dictatorship. The reflections that are proposed here attempt to explain this phenomenon, while at the same time looking at this particular context as an expression of other more general phenomena that affect Portugal and the European democracies as a whole today.

Keywords: youth, university, Coimbra, students, student movement, social movements, tradition, bohemia. 